\title{
QUAE CORPORE QUAESTUM FACIT: THE SEXUAL ECONOMY OF FEMALE PROSTITUTION IN THE ROMAN EMPIRE*
}

\author{
By REBECCA FLEMMING
}

\section{INTRODUCTION}

Prostitution, it seems to be generally agreed, was a phenomenon firmly embedded in imperial Roman society. It has, however, yet to achieve a similar level of scholarly integration. Moves are undoubtedly being made in this direction. Several topics which have a direct bearing on patterns of prostitution, or in which prostitution is implicated, such as the complex hierarchy of male and female, the patterning of erotic desires and pleasures, the acquisition and dissipation of wealth, and the organization of urban life, can certainly be described as major preoccupations in present enquiries into the Roman world; and a couple of monographs on the subject, or aspects of it, have recently appeared. ${ }^{1}$ None the less, there is as yet no study that can really bear comparison with any of the substantial historical works on prostitution in a range of other times and places that have been published in the last two decades. ${ }^{2}$ In particular, there has not been any serious effort to take the perspective of the prostitutes themselves into account, which is one of the most emphatic developments in the new historiography of prostitution emerging elsewhere.

This article, therefore, attempts to set out some ways in which this more recent body of historical research into prostitution might be productively brought to bear on the remains of Roman patterns of exchanging sex for money - remains already located in broader fields of interpretation and investigation within Classical studies. It does not seek to apply an established methodology for the study of past prostitutions, nor to extend an established model of their historical formation to the ancient world, for no such tools or templates exist; but more generally seeks to take advantage of prior historical problematizations of the sale and purchase of sexual services, of the possibilities already mapped out, the issues raised and connections made, for understanding prostitution in imperial Rome.

In these prior historical problematizations, prostitution is broadly construed as a changeable compound of two essential elements. The first is sexual availability, allegedly absolutely indiscriminate but actually wrongfully discriminating in a relative sense; availability deemed quantitatively and qualitatively mistaken. The second is economic

\begin{abstract}
* My thanks to Riet van Bremen, Di Paton, and the Editorial Committee of $\mathscr{H R S}$ for all their comments and suggestions.

1 'T. McGinn, Prostitution, Sexuality and the Law in Ancient Rome (1998) is so recent it appeared after this article was initially completed, and provides a much more systematic (though circumscribed) study of the legal rules affecting Roman prostitution than hitherto. B. Stumpp, Prostitution in der römischen Antike (1998) appeared a little earlier, but follows H. Herter's articles, 'Dirne', in RLAC III (1957), I I 49-I 2 I 3, and 'Die Soziologie der antiken Prostitution im Lichte des heidnischen und christlichen Schrifttums', $\mathscr{\exists} b A C_{3}$ (1960), 70-1 1 1, in providing a useful collection of material organized in a set of rather confused analytical categories; S. Leontsini, Die Prostitution im frühen Byzanz (1989), is a more coherent study but of a later period. A still earlier methodological tradition is represented by e.g. J. Balsdon, Roman Women: Their History and Habits (1962), 224-9, following K. Schneider, 'Meretrix', in $R E X V . I$ (I93I), I018-27, and the rather more liberal O. Kiefer, Sexual Life in Ancient Rome (1 934), 55-63,
\end{abstract}

who includes prostitutes in the section on 'free love' rather than 'less reputable women'. Both, however, consider prostitutes who had liaisons with famous poets to be the most blessed of women and worry about the public health consequences of prostitution in ways that never occurred to the Romans, but rather reflect the concerns of nineteenth-century reformers such as A. J. B. Parent-Duchâtelet, whose work De la prostitution dans la ville Paris considerée sous la rapport de l'hygiène publique, de la morale et de l'administration $($ I 836$)$ provided a model for similar works produced elsewhere in Europe and America, and has exerted considerable influence on historical studies of prostitution ever since.

2 Among the more notable of these are: J. Walkowitz, Prostitution and Victorian Society: Women, Class and the State ( 1980$) ; \mathrm{L}$. White, The Comforts of Home: Prostitution in Colonial Nairobi (1 99o); M. Wood Hill, Their Sisters' Keepers: Prostitution in New York City, I830-1870 (1993); R. Mazo Karras, Common Women: Prostitution and Sexuality in Medieval England (1996); and G. Hershatter, Dangerous Pleasures: Prostitution and Modernity in Twentieth-Century Shanghai (1 997). 
gain, which is part of the adjudged error in discrimination, but not necessarily the major part (and certainly not the whole). Prostitution is, therefore, at once a form of sexual activity, a kind of sexual style or category, and a form of economic activity, a way of making a living through the provision of certain services, by behaving in accordance with, or falling into, such a category. Some recent works have stressed the former aspect. Karras, for instance, argues that in medieval Europe, 'it was not the exchange of money, not even multiple partners, but the public and indiscriminate availability of a woman's body that was the defining feature of prostitution'; and her collaborative article with Boyd takes this a step further, claiming that in the Middle Ages prostitution was a 'sexual orientation', that it 'involved being a certain type of person, rather than engaging in sex for money', that is doing certain types of things, performing certain sexual acts. ${ }^{3}$ White, on the other hand, defines the prostitution she examines in colonial Nairobi as a type of reproductive labour, deriving from the economic needs and aspirations of the women involved, and their families, and meeting various, more social, needs of a new urban, male workforce. ${ }^{4}$

This divergent emphasis partly reflects the cultural specificity of past prostitutions - the fact that the wider set of circumstances and practices, norms and values, pertaining to both sex and wealth, within which prostitutions form and function, were not the same in medieval England and colonial Kenya - but it also reflects differences of scholarly resources and perspective within that framework. White uses, 'the language that comes from the work and experiences of prostitutes themselves', a language that passes to her through interviews and other oral reports. ${ }^{5}$ Indeed, the general academic adoption of that language lies at the heart of her bold attempt to re-orient the historiography of prostitution more broadly, to transform a literature that 'speaks of women's victimization' into one that speaks of 'women's actions' and earnings. Karras, however, has no such access to the voices of women in the Middle Ages, and, though sympathetic to these more empowering historical narratives, thinks they must be tempered by the view from outside; the negative view of the work of the prostitute which bears down, in varying ways and weights, on those who engage in it. She, therefore, tries to 'steer between the danger of portraying prostitutes as victims by concentrating too much on how others saw them and the danger of decontextualizing them by concentrating too much on their agency'. ${ }^{6}$

These debates about how women's history is both made and written have a clear resonance for enquiries in the Classical world, where the problems presented by the surviving sources are even more acute. This study thus sets out to examine the specific sexual economy of prostitution in the Roman Empire with these issues in mind. It seeks to find ways of using the scarce and slippery evidential resources of a literature produced by men of the imperial élite for their own particular purposes, and of material and documentary remains that are neither profuse nor unambiguous, to establish an outline of the imperial sex trade both as an institution, as a set of more or less clearly constituted and conceived economic, social, and ideative relations, and as a lived experience, as a field of intentional female activity. That is to explore, with this set of evidence, the possibilities of writing a history of Roman prostitution which forms part of the history of female labour, or of the history of sexuality, not to mention the more traditional history of social policy and a whole host of other histories. This exploration occurs, of course, within the broader historical frame of the Roman Empire itself. It is worth remembering at the outset that, for instance, the institution of slavery - one of the linchpins of empire - is a troubling one for labour history, and cuts across, though does not remove, issues of agency; and that the ancient world had its own distinctive

\footnotetext{
${ }^{3}$ Karras, op. cit. (n. 2), 1o; R. M. Karras and D. L. Boyd, 'Ut cum muliere: a male transvestite prostitute in fourteenth-century London', in L. Fradenburg and C. Freccero (eds), Premodern Sexualities (1 996), I04.

${ }^{4}$ White, op. cit. (n. 2), 10-21

${ }^{5}$ White, op. cit. (n. 2), 6-1o; Hill, op. cit. (n. 2),
}

also uses prostitutes' letters to help produce a study of the sex-trade in mid-nineteenth-century New York in which prostitution also appears as a rational economic choice for women, with its own 'positive appeal and rewards' (5)

6 Karras, op. cit. (n. 2), 9; see also the similar remarks of Hershatter, op. cit. (n. 2), 3-33. 
configurations of self and sexual activity. The point is, however, to use all the available resources to try and write a history of Roman prostitution that is not just a history of men's sexual choices and their regulation of the sexual objects they construct, but also of women's lives; that is, not a half, but a whole history.

This means not abandoning male-authored, male-centred texts, but recognizing them as such, and as less interested in describing the phenomenon of prostitution itself than in describing, in making and marshalling, its meanings for the literary élite. They need rather to be made to work harder than ever, with closer attention being paid to their formulations and framings and the way items in the archaeological and epigraphic records relate to them. In particular, this literature should not be coddled with assumptions about prostitutes and prostitution that can be traced back to the social reformers of the nineteenth century, but challenged with questions posed by more recent historical and sociological studies variously informed by feminism and the voices, views, and values of the working women themselves. The aim is to understand the partiality of the literary legacy, its incompleteness and imbalance, but as something none the less integral to the phenomenon itself - to an assemblage of human activities organized around an essential asymmetry, discrepantly, even conflictually, engaged in and interpreted by the different parties involved, who, at the same time, cannot avoid their mutual implication in the complex whole they enact. There are additional problems, of course, as even these élite voices are somewhat disparate in their distribution in time and space, and the material evidence is similarly scattered. So, while an attempt is certainly made to pull all this into a certain shape, to bring a kind of order to affairs, there is no effort to smooth out the differences of positioning and perspective, of locality and chronology; these must remain, with all their ramifications.

The overall approach is thus broad and thematic, rather than in anyway exhaustive, but there are also some specific boundaries necessary to make the project manageable. This is a study of prostitution in the Roman Empire before that Empire became Christianized; which is not to say that Christian evidence is ignored, but that it is used for what it reveals about prevalent 'pagan' practices, about the traditional (but not unchanging) attitudes and activities which Christian writers were working with and reacting against in various ways. And it is a study of female prostitution only. Women made up the vast majority, but not all, of imperial prostitutes, and this must be recognized in dealing with either part of the population. Though this article has little to say directly about male prostitution, it is hoped that it still provides the basis for its future examination; that it offers an introduction to the central elements that will need to be rearranged, reworked, and elaborated in many subsequent, more detailed, investigations into the unwieldy entirety of the sex-trade in the Roman world.

\section{LABOUR, LUST AND LUCRE}

The process of becoming a prostitute in the Roman world, becoming a meretrix literally a woman who earns (from the Latin mereo) - a hetaira or a pornê - a woman who sells (from the Greek pernemi) - is not a matter in which contemporaries evince much interest, in contrast to the concern that was eventually to develop in this area, with its complex classification of paths into prostitution centred around narratives of woman's 'fall' in which her victimization is writ large. Only a handful of reasons for women's prostitution are provided, more or less incidentally, by imperial writers; and though they eschew the more baroque styles of making woman victim, they do not exactly offer her much choice in the matter either. She might be prostituted, first and foremost as a slave or, secondly, as a wife or daughter; otherwise she herself might be driven to sell her body systematically by either her depraved lusts or indigence.

Dio Chrysostom assumes that the bodies set out as sexual wares in the cities of the Empire have been captured or purchased for the purpose, an assumption also worked with in the assorted stories that circulated in the imperial world of well-bred maidens 
captured by pirates or bandits and sold to brothel-keepers (lenones or pornoboskoi). ${ }^{7}$ Whether these statements about the slave supply are in fact accurate may be questioned, but the basic premise that prostitutes broadly become such through enslavement (or, at least, that the great majority of prostitutes are slaves) is certainly borne out in numerous sources, many of which will be discussed in due course. ${ }^{8}$ Justin Martyr alleges not only that almost all exposed children (not just the girls) were raised for prostitution, presumably as slaves, but also that pagans commonly sold the sexual services of their own offspring and wives. ${ }^{9}$ This latter accusation is supported, without the religious qualification, by the legislation of early Christian emperors formalizing at least one means of escape for daughters from 'lenones patres', that is, fathers who prostitute them. ${ }^{10}$ The practice is unlikely to be a recent development, even if this extension of jurisdiction into the family domain and the remedy offered - centred around appeal to a bishop - are. Moreover, a similar scenario, in which the mother replaces the father as prostitutor, is imagined both in a fourth-century A.D. papyrus which recounts an Alexandrian court case in which some of the drama is provided by a mother claiming compensation for the loss of her livelihood caused by the murder of the daughter whom she had placed in the control of a pornoboskos so that neither of them might starve, and in Lucian's dialogue between a mother and the daughter whom she has just made turn her first trick so that they might exchange poverty for a life of luxury. ${ }^{11}$ As for husbands prostituting their wives, Firmicus Maternus describes a natal celestial configuration that means a husband or wife will, respectively, compel or suffer sexual availability for profit; and in his Apology Apuleius accuses his arch enemy Herennius Rufinus of turning his house into a brothel, with his wife as the main attraction, in order to make ends meet after having dissipated a dubious inheritance. ${ }^{12}$ There is every reason to think that Apuleius is, at the very least, exaggerating, but the basic plausibility of the situation seems assured.

It is Firmicus too who expresses most explicitly the, more widely hinted at, notion that a woman's licentiousness might dictate her livelihood to herself:

si vero mulier sic Venerem positam habuerit, <erit> impura libidinosa et ad omnium exposita voluptatem et meretricis semper actibus implicata, quae propter necessitatem vitae in meritorio se statuat vel lenoni locet.

If a woman has Venus in this house, she will be full of vile lusts, accessible for the pleasure of all, and always in thrall to the impulses of a meretrix; on account of the necessity of this life she will set herself up in the business, or contract to a leno. ${ }^{13}$

Ulpian rejects poverty as an excuse for living a turpissima vita ('most sordid life') in his definition of those women whose conduct places them on the wrong side of the Lex Julia et Papia in respect to their marriageability, and Lactantius is only a little more sympathetic to women whom necessity forces to profane their chastity. ${ }^{14}$ Both seem to

${ }^{7}$ Dio, Or. 7.133, and see also Cod. 8.50.7. Stories of enslavement and prostitution feature in Sen. Contr. 1.2, the Hist. Apoll. Tyr. 33-7, Xen. Eph. 5.5-9, and Apul., Met. 7.9-10. Women's fierce resistance to the logical consequence of such a fate - that she should lose her virginity to the wrong man in the wrong circumstances - is the centrepiece of such stories, so there are some limits to her victimhood.

8 W. Scheidel, 'Quantifying the sources of slaves in the early Roman Empire', $\mathscr{F} R S$ 87 (1997), i 56-69, argues that slave reproduction was actually the greatest source of supply. Whether any such reproduction would have occurred within the brothel itself is unclear, certainly the implication in most sources is that prostitutes successfully strove not to reproduce, which recent studies on the efficacy of ancient methods of contraception and abortion might help explain, see esp. J. Riddle, Contraception and Abortion from the Ancient World to the Renaissance (1992).

${ }^{9}$ Justin, Apol. 1.27. Exposing children thus raises the alarming prospect of committing, not only fornication, but also incest, when visiting a brothel, and so is definitely not to be practised by Christians. Lactantius (Inst. 6.20.22) repeats the accusation, but with the qualification that exposed children end up either in slavery or the brothel ('vel servitutem vel ad lupanar') though this opposition should probably not be pushed too hard.

10 Cod. 1.4 .12 and $11.41 .6(=C T h$ 15.8.2). The measure deals with masters as well as fathers.

${ }^{11} B G U$ IV $1024.8-18$ and Luc., DMeretr. 6. On the more imaginative aspects of the Alexandrian court case, see J. G. Keenan, 'Roman criminal law in a Berlin papyrus codex (BGU IV 1024-1027)', $A P 35$ (1989), I 5-23.

${ }_{12}^{12}$ Firm., Math. 6. I r.6; Apul., Apol. 75-6.

${ }_{13}$ Firm., Math. 3.6.22; see also e.g. 7.25.9.

${ }^{14}$ Dig. 23.2.43.5; Lact., Inst. 5.8.7; see also the judge's remarks at $B G U$ IV $1024.20-30$. 
be speaking, at least primarily, of situations in which these factors act directly on the woman, who has made herself into a meretrix as a result.

So, becoming a meretrix is, as the word suggests, primarily understood as an economic act, but one that belongs far less to the prostituted woman herself than to those around her; to those who profit from her initial and recurrent sale. The modern verdict that, 'Money is the reason for prostitution', may be borne out by the ancient sources, but the money in question is presented not as an incentive for entering the profession, as it is now, but for establishing others in it. ${ }^{15}$ The existence of the institution of slavery, and the profits to be realized from its intersection with prostitution, clearly play their part in establishing this pattern. Beyond that, it is also hardly surprising that prostitution was less an individual undertaking than one which occurred within a more complex, and frequently familial, economic network. Nor should the sources' respect for hierarchies of power and agency within this collective context be taken as at all peculiar. It might well seem that the costs and benefits are unequally distributed in a family which, directly or indirectly, prostitutes its womenfolk, but the precise combination of consent and coercion involved in such circumstances is not revealed.

Apuleius does have Rufinus' wife eventually resign in some disgust from her position as family bread-winner but not wife, though this is essential to his plot in various ways and no doubt primarily intended to reflect badly on her husband, and the later imperial legislation also indicates that at least some daughters wanted, and tried, to get out of parental prostitution. However, while Rufinus clearly had other economic alternatives open to him, this is far less obvious for the mothers who sold their daughters, though the financial expectations from such sales appear high. Moreover, a comment by Sextus Empiricus that some Egyptian girls accumulate their dowry through prostitution, though highly dubious in itself, at least raises the possibility that prostitution could be undertaken short-term with a very specific goal in mind, and it also serves to underline the point that in the Roman world in general a daughter's sexual choices, her control over her body, were severely limited. ${ }^{16}$ Her sexuality was, in a real sense, for her father and family to dispose of, either in marriage or otherwise.

The problematic nature of these few sources makes it impossible to push them very far on any of these issues. Female bodies clearly counted amongst the economic resources not only of slave-dealers and owners, but also of any family network, available short- or long-term for the avoidance of penury and probably in some cases also for the pursuance of more particular and ambitious economic strategies. How of ten they were deployed, and how this worked out within the family, as a source of what must have been obligation, support, and conflict, is unclear. ${ }^{17}$ Both these mechanisms of prostitution were, broadly speaking, deemed legitimate in the Roman world; they function within two of its most basic power structures. Slaves and daughters in particular were legally positioned so they could be prostituted, and though there were various qualifications to this which will be discussed later, even the Christian legislation did not alter the underlying situation. That they could be, does not of course mean that they should be; the reporting is largely censorious; but attitudes amongst those lower down the social order and thus most likely seriously to consider prostitution amongst their restricted economic options, rather than attitudes of the élite towards them, are unknown.

Firmicus' ascription of a sexual motive to those women celestially destined to become meretrices stands out against this predominantly economic pattern, and it is also noteworthy that it is at this point that the women themselves emerge most clearly as individual actors. He does not, however, exactly figure prostitution as a sexual orientation or identity as distinct from a set of sexual activities. Nor does he quite

15 C. Høigård and L. Finstad, Backstreets: Prostitution, Money and Love, trans. K. Hansen, N. Sipe and B. Wilson (1992), 40; and see also e.g. N. McKeganey and M. Barnard, Sex Work on the Streets: Prostitutes and their Clients (1996), 26. These are, of course, sociological studies of prostitution itself rather than of popular views of it and its causes.

\footnotetext{
${ }^{16}$ Sext. Emp., $P_{3.201}$.

17 Hershatter, op. cit. (n. 2), 18 $81-209$, discusses circumstances and contexts for the selling or pawning of daughters into prostitution in early twentiethcentury China, which may give some clues in this respect.
} 
suggest, as was to become a nineteenth-century conviction, that some women are born prostitutes. ${ }^{18}$ What some women are born with are certain lusts, with the impulses of a prostitute', which she can, or must, then make into her trade, her career. Firmicus thus constitutes the meretrix as a woman who realizes the professional potential of her innate desires, whose identity is bound up with the performance of certain acts of a financial as well as sexual character, the making of this condition into a way of life.

These different ways of entering prostitution are connected with the different forms the institution took. The prostitution of slaves was paradigmatically based in brothels lupanaria and fornices, porneia and ergasteria - but also in a range of other establishments, such as inns, taverns, and bath-houses. These places were managed by lenones, pornoboskoi or, less frequently, lenae, who were in the business of making their denizens sexually available; the verb describing this causative activity being 'prostituere', literally 'to place before', 'to set out' (of wares). ${ }^{19}$ 'The organization of life in a lupanar is described, at least in outline, in the Elder Seneca's Controversia on the issue of whether a virgin kidnapped by pirates and sold to a leno who established her in a brothel, but who none the less managed to preserve her virginity with entreaties and a sword, is permitted to hold a priesthood once she had returned to her family. ${ }^{20}$ Many of these same features also occur elsewhere in the ancient literature. The slave lupanar appears as an enclosed world, with the women confined to the premises, their basic needs provided for by the leno who rules his domain in a cruel and coercive manner, driven by greed and depravity. ${ }^{21}$ He sets the prices, displayed along with the woman's name on the tituli set over the entrances to the small cellae in which they worked, and he takes the money. ${ }^{22}$ None the less, the women themselves form some kind of community, as they share meals and intimacies, welcoming new arrivals with kisses and training them in the tricks of the trade.

These literary brothels are located in a range of times and places, from the contemporary Rome and Puteoli of satire, to the vaguely historical Tarentum and Mytilene of the novels. Whether the Roman model of their organization should in fact be applied outside Italy, where it has some archaeological support, at any time is however unclear. Certainly Xenophon of Ephesus, writing in Greek, presents a slightly different picture of brothel arrangements than the Latin texts, but other Greek works have little to offer on the matter. Pornoboskoi and slaves appear in relation to city brothels (koineia poleôs) in a fragmentary Arsinoite papyrus dating from A.D. 265, but without any indication of internal organization beyond that, and, in interpreting dreams involving prostitutes in brothels, for instance, Artemidorus specifies neither the status of the women nor the regime under which they live. ${ }^{23}$

The elaborate details of Roman brothel life find their way into Seneca's Controversia because they serve a clear rhetorical purpose. They substantiate the claim made by several of the speakers that, regardless of the circumstances and her actual virginity, once a woman enters a lupanar, temples are closed to her. Once she has been set up by a leno as sexually accessible to the general populace - the titulus being the potent marker of this availability - and has lived as a meretrix among meretrices, then, even if no man actually gains access to her, even if she has not in fact worked as a meretrix, her chastity is forfeit. These speakers also effectively expose the acute asymmetry that characterizes Roman prostitution, for no such penalties were incurred by a man who entered a brothel

\footnotetext{
$18 \mathrm{Kiefer}$, op. cit. (n. I), 59, quotes, for example, a comment by a contemporary German sexologist that, 'One is born a wife just as one is born a prostitute; and no woman who is meant for free-love becomes a wife by being married'.

19 With one partial exception, slaves fill all literary brothels where the status of their denizens is clear; the sort of exception is provided by the empress Messalina at Juv. 6. I $16-32$, though the status of the other, more regular, women in the brothel is not clear, and there are also several ambiguous cases.

${ }^{20}$ Sen., Contr. I.2.

21 The nastiest, most avaricious, literary leno is undoubtedly that in the Hist. Apoll. Tyr. 33-7;
}

Xenophon of Ephesus' Tarentine parnoboskos, on the other hand, shows some redeeming qualities at 5.7-8. The slave collar of a meretrix from Bulla Regia in Africa ( $I L S$ 9455) also emphasizes the coercive element of prostitution.

${ }_{22}$ The tituli and cellae are the most regular feature of Latin literary lupanara, see e.g. Petr., Sat. 7-8, Juv. 6.1 16-32, and Mart. I 1.45. Cellae are also found in the famous Pompeian lupanare at VII.12.18-20.

${ }^{23}$ PSI IX 1055a and Artemidorus 1.78, cf. 4.9. For Greek brothels of an earlier age see J. Davidson, Courtesans and Fishcakes: The Consuming Passions of Classical Athens (1997), esp. 83-9 I . 
as a customer. Indeed, the Elder Cato is famously reported to have greeted a wellknown gentleman leaving a fornix with the congratulatory phrase, 'macte virtute esto' ('Well done!'), praising his decision to assuage his lust with prostitutes rather than other men's wives; though he later added, after meeting the same man in the same situation a number of times, that his approbation extended only to the occasional visit to the brothel, not to making it home. ${ }^{24}$ Despite, indeed because of, her degradation and dishonour, the meretrix was a perfectly proper sexual object for the Roman man, but one to be enjoyed, like everything else, in moderation; the sexual services she provided were socially useful, though not without qualification.

These twin themes are explored most fully in imperial Latin literature in the pair of major declamations ascribed to Quintilian which argue both sides of the case of a poor man who accuses a meretrix whom he loved of poisoning him with a hate potion. ${ }^{25}$ The pauper first claims credit for the propriety of his conduct, for pursuing permissible passions, not destroying anyone's marriage; he attacks the prostitute for her profession in general, and her particular use of it to ruin him, as she insinuated herself into his affections, took all his money, and then rejected him as insufficiently lucrative. The woman's advocate also claims that she has behaved admirably (as far as her circumstances allow), causing no matrimonial discord, no paternal complaint, no impoverishment, and seeking only to curb the increasing immoderation of her suitor. A single declamation of Libanius opposing the return of the legendary hetaira Lais to Corinth, though it initially seems to present a rather more austere argument than pseudoQuintilian, actually runs along much the same lines, just set in a somewhat mythical Greek past. ${ }^{26}$ The motivation for her recall is that adultery has increased since her exile, resulting in a high death-toll among young men caught, and thus lawfully killed, in the act. Libanius counters that Lais is the cause of the problem and cannot resolve, only worsen it. For she not only acted as a drain on the community's economic resources, as families' wealth ineluctably found its way into her coffers, but also on its moral resources, as she took men away from their wives who then sought to emulate the woman who was so successful where they had failed, and whose depravity has now become habitual. Self-control (sōphrosunê), honour, and piety all demand, therefore, that Lais should remain as far away from Corinth as possible. This is not, however, an argument for the removal of all prostitutes from the city, but applies to Lais alone. Indeed, if the allegations made by Libanius' putative opponent that the original motion of exile was instigated by the more lowly (adoxoi) local hetairai and their pornoboskoi in order to protect their trade are true, then they should be thanked for it. The implicit point is that these prostitutes do, in their humble and rather unsavoury way, provide a useful service, while Lais takes matters far beyond that into areas of flagrant excess and dissipation. Similar distinctions, similarly drawn in the territory of the Greek past, can be found in Athenaeus, particularly when Cynunculus warns his fellow-diners against involvement with fabled ladies such as Lais, while recommending the use of the hetairai of the brothels and booths (oikêmata), whose function is plain and who are, therefore, easily available to all at low cost. ${ }^{27}$

There were those who took a different line. Libanius' arguments are a weaker version of those used by Dio Chrysostom as he demands the business of the pornoboskoi be completely banned from city life. That is he directs his energy precisely against what others deemed the acceptable face of prostitution, a prostitution of the present rather than a romantic, if dangerous, past. ${ }^{28}$ For Dio, not only does the open availability of some women undermine rather than protect the non-availability of others, as prostitution is the start of a slippery slope into, rather than a buttress against, deeper depravity and licence, but it also, given that this availability is something forced upon slaves, transgresses against the basic honour in which all humanity is held by god. Proper sexual activity, Dio implies, occurs within a proper and productive relationship between

\footnotetext{
24 The initial praise is quoted by Hor., Sat. 1.2.3 $1-2$; the sequel is provided by a scholion in the pseudo-Acronic collection.

${ }^{25}$ [Quint.], Maj. Decl. I4-15.
}

${ }^{26}$ Lib., Decl. 25; the general theme seems to be a standard one, see Rhet. Gr. 8.409 (Walz).

${ }^{27}$ Ath. 13.566e-71a.

28 Dio, Or. 7.133-52. 
man and woman, and Musonius Rufus, the Stoic philosopher who probably influenced Dio, states this explicitly. ${ }^{29} \mathrm{He}$ counts sex with prostitutes, like any other extra-marital intercourse not intended for the procreation of children, as demonstrating a reprehensible lack of self-control. The tone of Musonius' diatribe, however, makes it clear that he realizes himself to be advocating a minority view within society; and the surviving sources certainly bear this out.

The more general construction of the lupanar or fornix as a place where contemptible female behaviour and creditable, though not unproblematic, male behaviour, meet, with the acceptance of the latter dependent on the unacceptability of the former, is also apparent in the more moralistic descriptions of the establishments themselves. On the one hand, these are sordid places, smelly and sooty, degraded and unsavoury - places of vice and venality, of soft pleasures and hard deceit. ${ }^{30}$ On the other hand, the brothel maintains a certain propriety as a locus of prostitution, a certain status as a structured, even controlled, site of sexual availability; what goes on here is properly concealed behind closed doors, and there is a straightforward simplicity about what is on offer, an honesty to the pretence. ${ }^{31}$ Similarly, as Wallace-Hadrill has argued, the urban location of commercial and service activities, especially those trading on various kinds of bodily satisfaction, at a respectful distance from the active centres of public life, of law, politics, and religion, should not be seen as inhibitive, but rather the reverse, as creating the appropriate context in which the less virtuous, but none the less integral, aspects of city life could flourish. ${ }^{32}$

These descriptions, and the wider discourse on prostitution, also make it clear that these lupanaria cater primarily for the poorer, rougher, end of Roman society; and the names appearing in the graffiti most securely attached to the selling of sex in Pompeii tend to confirm this, suggesting also that male slaves made up a significant proportion of the clientele. ${ }^{33}$ But it is these same locales, not any special, more refined, establishments, that also count the upper classes among their customers. It is his social equals and betters that Horace berates, whether they prefer their women in the full dress of the matron, or 'olenti in fornice stantem' ('displayed in a stinking brothel'), and the poor victim of the hate potion, convinced as he is that prostitutes were invented so that there should be something 'quod liceret amare pauperis' ('that a poor man is allowed to make love to'), has to compete with the wealthy for the attentions of his beloved meretrix. ${ }^{34}$ Indeed this is the point. The service provided by brothels is a service to all men and the low standards necessary to maintain that availability to the poor acted as a restraint against the potential excesses of the rich in this respect also; it made their place in the sexual life of the élite plain. The vulgarity of these locations, both in the sense of their wide catchment and their tawdriness, was proper to them, both defining and fitting, indicative of and conducive to their rightful use. That fornices were generally filled with slaves also forms part of their baseness, and its propriety. This status guaranteed that there was no other man but the leno who had any claim on the woman, indeed guaranteed that she had no claim on herself; it was a position wholly in accord with the operational terms of the lupanar.

All this, however, leaves the women themselves sunk in sordidness, fully bound by the necessary, and necessarily degrading, conditions for their social utility; able to gain meagre moral credit for conforming particularly closely to the terms on which that utility was constituted but still kept within the overall framework of censure and contempt. This is, of course, the view from the outside, or rather, a view from a very particular external vantage point. This is the lupanar as it is located in the sexual and ethical world of the authorial élite; not as it was located in the world of most of its

${ }^{29}$ Muson., Fr, 12 (Lutz) and see e.g. C. P. Jones, The Roman World of Dio Chrysostom (1978), 12-18 for his relations with Dio.

${ }^{30}$ See e.g. Juv. 6.121-32 and II.172-3; Hor., Sat. I.2.30; Sen., Vit. Beat. 4.7 .

31 See e.g. Mart. 1.34.5-6 and 2.53.7; Hor., Sat. I.2.83-5 and $101-5$; and Ath. 13.569a-f.

${ }^{32} \mathrm{~A}$. Wallace-Hadrill, 'Public honour and private shame: the urban texture of Pompeii', in 'T. J. Cornell and K. Lomas (eds), Urban Society in Roman Italy (1995), 39-62.

${ }^{33}$ CIL IV.21 $73-296$ and $C I L$ IV.3929-43; see on the identification of brothels etc. in Pompeii, WallaceHadrill, op. cit. (n. 32), 53 with notes.

${ }^{34}$ Hor., Sat. 1.2.30; [Quint.], Decl. Maj. 14.8, and see also 15.7 and $9-10$. 
clientele, and still less as it was occupied, experienced, by women who, despite their enslavement, surely had their own aims and values. Indeed, these must inevitably have been at odds with those of their richest and most articulate customers. For it was precisely those features of the brothel that made it a valuable institution - its enclosure and control of a suitable group of women's sexual availability to the populace - that bore down most heavily on its inhabitants, that acted most restrictively on any kind of female self-determination, reducing any room for manoeuvre, and which must have meant that their main objective, beyond simple survival, was escape.

Both the reach of the leno and the implication of slavery in Roman prostitution extended beyond the confines of the lupanar, but precisely how far and in what direction is hard to discern. The pornoboskoi of Dio Chrysostom have, as their name suggests, flocks of slave prostitutes in their charge, stationed in oikêmata all over the cities in which they make their obscene profits or driven from festival to festival in search of rich takings. ${ }^{35}$ And though lenones do not feature directly in transactions with meretrices who solicit in front of individual cellae in Rome, their presence behind the scenes is not hard to envisage; while Juvenal speaks of girls 'ad circum iussas prostare' ('ordered to display themselves in the circus'), suggesting that at least some of the women who sold their bodies in public places might be at the bidding of, if not owned by, a leno. ${ }^{36} \mathrm{It}$ is possible, however, likely even in the larger cities where control over the sex trade and its workers would be harder to exercise, that some of these outdoor meretrices - those who solicited in the open and serviced their customers where they could, who operated without recourse even to an oikêma or cella - worked independently, or at least within an economic network from which the figure of the leno was excluded. ${ }^{37}$ Several Egyptian ostraka also show the authorities dealing directly with prostitutes themselves, not intermediaries, including permissions to trade sexually in their cities on certain days, indicating that some peripatetic prostitutes might at least be free, if not more broadly autonomous. ${ }^{38}$

This kind of autonomy creates the possibility of exercising (within certain limits) some degree of control over services offered and to whom, a control notably lacking from most of the literature. The only clear case of a meretrix who was able to refuse a paying customer is Republican in origin, though recorded by Aulus Gellius. ${ }^{39}$ This is the story of the drunken aedile - Hostilius Mancinus - forcibly prevented from visiting the meretrix Manilia, whom he then tried to prosecute for injuries sustained as he was repelled from her door, a prosecution disallowed by the tribunes who upheld Manilia's decision not to admit such a reveller. Nothing so explicit emerges from the imperial period itself, though such independent establishments are sometimes hinted at. Indeed, it is perhaps this kind of situation that Firmicus counterposed to contracting to a leno for those celestially destined for a career as a prostitute. In general, however, the meretrix is marked, even defined, by her absolute availability. It is the ease of access to, the simplicity and clarity of transactions with, professionals, that poets praise in contrast to the difficulties, the convolutions, and uncertainties of involvement with amorous amateurs. The same openness is viciously attacked by the prosecuting pauper in the Quintilianic case of the hate-potion. He demands of his opponent:

\footnotetext{
35 Dio, Or. 7.133 and 77-78.4. There is no hint of anything other than an economic motive being involved in prostitutes' presence at these festivals, as also for their presence around temples. Prostitutes did also participate in the religious life of the community like any other group but none of this bears any resemblance to notions of 'sacred' or 'temple' prostitution that have come to form such a potent part of the historical imagination (on which see generally M. Beard and J. Henderson, 'With this body $I$ thee worship: sacred prostitution in antiquity', Gender and History 9 (1997), 480-503).

36 Such cellae - single rooms with masonry beds
}

that open directly onto the street - have been found in Pompeii, see Wallace-Hadrill, op. cit. (n. 32), 53 with notes, and their operation seems to be referred to in Ov., Am. 3.14.9-10, Mart. 1.34.5, and Juv. 3. $134-6$. The prostitutes at the circus are at Juv. 3.65 ${ }_{37}$ See e.g. Prop. 2.23.13-16; Juv. 6.OI6; and Mart. 3.93 . I 5 for references to these outdoor operations.

${ }_{38}$ All are from Elephantine: $O$.Wilck. $8_{3}$ and $1_{1} 57$ are both dated to A.D. I I I; and $S B$ VI 9545 n. 33 and IV 7399 to A.D. I 42 and 144 respectively. Any travelling worker in Egypt needed local leave to pursue their trade in this way.

39 Gell. 4. I 4. 
tu, cui non licet excludere debilitates, fastidire sordes, exposita ebrietatibus, addicta petulantiae, [et] quaeque novissima vilitas est, noctibus populoque concessa, mores iuventutis emendas?

You - who may not shut out cripples or disdain the dregs of society, who are accessible to the drunk, sold to the wanton, and, which is the ultimate in cheapness, granted nightly to the public - do you seek to correct the conduct of a young man ? ${ }^{40}$

Rather than discussing, or ordering, different forms of prostitution according to the amount of control they afford to the women involved, therefore, contemporaries were more likely to assume, or assert, that the absence of autonomy was an integral part of being a meretrix. She might resent it, as does the meretrix who curses the imperium of her leno in one of Ovid's Amores, but it is still her most salient characteristic. ${ }^{41}$ While this attitude is hardly surprising, the lack of Roman interest in distinctions of prostitutional practice, or the constitution of a professional hierarchy generally, is more striking in its contrast with the concerns of many more modern commentators. The Latin language may be rich in words for 'prostitute', but, outside the plays of Plautus and their lexicographical legacy, these different terms carry differentials of tone, connotation and emphasis rather than of status, methods of soliciting, and service provision. ${ }^{42}$ 'Prostibulum' may once have designated a meretrix who made herself available in front of a stabulum, for instance, but in the imperial era it is employed either as just another derogatory term for a prostitute, or to denote a brothel. ${ }^{43}$ The much more commonly used noun 'scortum', which derives from the word for 'hide' or 'leather', differs from meretrix essentially in the pejorative force it applies to the same persons or phenomena; and even lupa - literally a 'she-wolf' - simply takes this condemnation a step further. ${ }^{44}$ Similarly, whatever their original difference, the Greek words pornê and hetaira are used almost interchangeably under the Empire. Hierarchies of the kind Davidson has recently tried to resurrect for Classical Athens, with its 'numerous gradations between the miserable life of the streets and the comfortable existence of the most successful courtesans', are a thing of the past, however much that past is treasured by authors such as Athenaeus. ${ }^{45}$ Figures such as Lais do not make it beyond the Hellenistic period. Volumnia Cytheris, mainly associated with Anthony but also with Gallus and Virgil, perhaps comes closest in Republican Rome but is apparently a one-off; and the mistresses of poetry who bear a more recurrent resemblance to the fabled courtesans of Greece are also made markedly different from them in other respects. ${ }^{46}$ They are, for instance, significantly not named as meretrices, however their situation has been subsequently interpreted; while neither Libanius nor Athenaeus, nor any of his speakers or sources, has any hesitation in labelling Lais and her ilk, as well as the denizens of the cheapest brothels, hetairai ${ }^{47}$

40 [Quint.], Maj. Decl. I4.7.

${ }^{41} \mathrm{Ov}, \mathrm{Am}$. I.10.21-4.

42 On the Latin vocabulary see J. N. Adams, 'Words for "prostitute" in Latin', $R h M$ i 26 (1983), 321-58; in which, partly through an emphasis on the Republican period, a somewhat different overall view of the terminology is taken than that expressed here.

${ }^{43}$ Tert., Apol. 6.3 and Amm. 28.4.9 both use prostibulum (or the feminine prostibula) to designate meretrices; the word is used for a brothel at Vulg. Ezech. I6:34 and Hist. Apoll. Tyr. 33 (earlier recension).

${ }^{44}$ Paul the Deacon summarizes Festus: 'scorta appellantur meretrices, quia ut pelliculae subiguntur. omnia namque ex pellibus facta scortea appellantur ('scorta are what meretrices are called, because they are worked like hides. For all things made from hides are called scortea.') (443.6-7 Lindsay; the Festan text at $442.13^{-1} 7$ is longer but badly fragmented). Later writers offer two explanations for the figurative formation of lupa: the commentator Servius (In Virg. Aen. 3.647 ) considers the connection between woman and beast to be a shared obscenity and odour, while
Isidore of Seville (Etym. 10.163) refers to the rapacity of the she-wolf as she captures her unfortunate prey. ${ }^{45}$ Davidson, op. cit. (n. 23), 77. See also Hershatter's description of the professional hierarchy in imperial China, which raises the possibility that these hierarchies are always, to a degree, things of the past, that nostalgia is part of the 'shared imaginary' through which they are constituted (op. cit. (n. 2), 34-65).

${ }^{46}$ For Cytheris see e.g. Cic., Phil. 2.58; Plut., Ant. 9.4; and Serv., Comm. In Verg. Buc. 10. If Suetonius' work, entitled by John Lydus in the only remaining reference to it Peri Episêmôn Pornôn/On Illustrious Prostitutes (Mag. 3.64), had survived it might (or might not, since what Lydus takes from it is entirely mythical) alter this picture.

${ }_{47}$ For discussion of the poetic evocations of these mistresses and their relationship to Roman social reality see, e.g. J. Griffin, 'Augustan poetry and the life of luxury', $\mathcal{F} R S 66$ (1976), 87-105; D. Kennedy, The Arts of Love (1993), esp. 83-103; and M. Wyke,

'Mistress and metaphor in Augustan elegy', Helios I 6,1 ( 1989$), 25^{-47}$. 
The term scortum, or more often its plural, is mainly used in a moralizing context, to encapsulate concisely the disreputable aspects of the meretrix both as she exists in herself and as she is associated with. It is for a scortum that 'honestum officium' ('proper duties') are postponed on the road to ruin sketched out (for its avoidance) by Horace in one of his exhortatory epistles to Lollius, for instance; and Seneca the Younger also warns that life may be wasted 'in complexu scortorum aut vino' ('in the embrace of whores or wine'). ${ }^{48}$ Lupa is employed in more extreme cases, where the contempt is for more than the woman's profession and its attendant dangers. The nasty foreign whores that Juvenal takes such exception to, along with the men that fancy them, are lupae barbarae; and when Martial wants to trump Ovid's unfavourable comparison of the conduct of his flagrantly unfaithful mistress with that of a prostitute who modestly does business behind closed doors, it is the behaviour of spurcae lupae ('filthy whores') who none the less have the decency to use tombs as concealing shelter for their activities that he evokes as worse than that of more discrete and domestic meretrices, but still not as reprehensible as his Lesbia in actually wanting witnesses to her infidelities. ${ }^{49}$ Prostitution is, therefore, no undifferentiated phenomenon, but one understood to be engaged in by those both buying and selling sex in manners more or less morally valued, more or less socially sanctioned, and it is thus differentially deployed in a range of ethically charged and culturally conformative discourses, in which both male and female conduct comes under scrutiny and pressure. The behaviour least at issue here, however, is that of the prostitute herself, and this is still a long way from the articulation of any kind of proper professional hierarchy.

All this, of course, takes no account of the issue of price, or earnings, which, it might be claimed, does provide an objective order of a kind; but here too things are neither simple nor straightforward. There was a prostitutional price scale in operation in the Roman Empire: inscriptions record a range between one and twenty-three asses, with two asses as the clear mode, but give few indications about the range of women and services to which they were attached. ${ }^{50}$ The second-century A.D. tax law of Palmyra, which uniquely contains within it a ranking of prostitutes' prices, simply lists hetairai who receive one denarius, eight, and six asses respectively without any further definition. ${ }^{51}$ Literature shows a concern with transactions occurring both at the bottom of this scale and off its other end entirely, but not with what happens in between, that is with the overall cost structure, and certainly not with the livelihood of the women involved.

The sex for one or two asses that appears, for instance, in a couple of Martial's epigrams, does so as a measure of men's miserliness, or moderation, while the income of a legionary tribune easily given by a rich man's slave to some Calvina or Catiena for his occasional enjoyment of her body, in Juvenal's third satire, provides a shocking contrast to the hesitation of an upright son of poor but free folk before he approaches some openly soliciting scortum, a Chione, whose face takes his fancy. ${ }^{52}$ That the former is not named as a meretrix in any way, that she is given - not necessarily paid - her substantial reward while maintaining some control over what it is for, fits in, moreover, with the general pattern of presentation of such ladies who do not inhabit the world of

${ }^{48}$ Hor., Ep. 1.1 8.34-5; Sen., Brev. Vit. 16.4, the corrupting combination of scorta and vinum is standard, see also e.g. Livy 23.45 .2 and Nep., Dion 4.4.

${ }^{49}$ Juv. 3.66; Ov., Am. 3.14; Mart. I.34. The figure of the whore who services her customers in cemeteries, or stands naked in a stinking brothel, is also used as a most extremely unlikely guardian of basic standards of propriety, standards scandalously let slip by her social superiors, at Juv. 6. O I 4-O I6 and I I I 7 I-3. Apuleius also uses the shocking juxtaposition 'uxor lupa' to describe the wife of Rufinus at Apol. 75 .

50 The evidence is collected by Stumpp, op. cit. (n. 1), 21 6-I 7 and T. McGinn, Prostitution and fulioClaudian Legislation: The Formation of Social Policy in Early Imperial Rome (unpub. $\mathrm{PhD}$ diss., University of Michigan, I986), 22-3.
51 CIS II iii.391 3 and see J. Matthews, "The tax law of Palmyra: evidence for economic history in a city of the Roman East', $\mathcal{J} R S$ 74 (1984), I 57-80 and further discussion below. It is worth mentioning that the earlier Palmyrene version of the law translated hetairai as 'slave girls' ( $P_{1}$ 122) implying that prostitutes were slaves in Roman Palmyra.

52 Mart. 2.53 and I.103; Juv. 3. 1 32-6. The ludicrous price put on Tharsia in the lupanar of the Hist. Apoll. Tyr. (33) - half a pound of gold initially, one aureus/ I00 HS thereafter - surely simply befits her status as a beautiful princess, rather than anything else. As $R$. Duncan-Jones says about the novel in general: 'Figures that have dramatic meaning but no external significance predominate among the prices' (The Economy of the Roman Empire (2nd edn, 1982), 252). 
fixed fees but of looser and larger exchanges of gifts and services, of relationships formed on terms quite distinct from those on which prostitutes do business, and often take literary form, as here, in contradistinction, if not counterposition, to meretrices themselves. ${ }^{53}$ This contrast, in Juvenal, is to illustrate the gross inequities in the distribution of rewards and respect in corrupt, contemporary Rome; the wrong man gets the wrong girl, just as he gets the wrong preferments, legal judgements, and so on. But in Ovid, for instance, it serves to police the behaviour of these more refined ladies, to make sure they do not pass over into prostitution, a particularly sordid prostitution since their degradation would then be self-wrought, not forced by another, and in Libanius and Athenaeus it is a not unrelated distinction that is used to police the behaviour of men. ${ }^{54}$ In all this, therefore, there is less of a hierarchy of women's prices than one of men's conduct, in particular their sexual purchasing power. Those at the top are able to operate in both the realms of the meretrix and the mistress, their dual position further enabling them to use the figure of the meretrix to keep their mistresses in line, but also bringing additional responsibilities about how they exercise their choices.

Within the ranks of the meretrices themselves, within the realm of fixed fees represented by the epigraphic evidence, there is still, moreover, a crucial distinction between price and income. Even if the common inference that outdoor meretrices occupied the lower rungs of the price scale while a meretrix such as Manilia commanded the higher prices, with the ladies of the lupanaria somewhere in between is correct (and comparative material certainly suggests something of the kind), similar differentials of income do not necessarily follow. For the fee for a single encounter is inversely proportional to the frequency of such encounters, and modern studies indicate that the higher earnings belong not to the more expensive call-girl but to the cheaper streetwalker, with low outlays and high productivity. ${ }^{55}$ High productivity may have its downside, but so, at least according to the hookers of present-day Oslo, do high prices: 'The more customers pay, the more of yourself you sell', they say. ${ }^{56}$ 'There is also the question of the time-scale involved and the economic objectives pursued. Street-walking may be better adapted to a strategy requiring rapid financial accumulation over a short period of time, and in which migrancy is implicated; whereas the more settled, service oriented, operations of women who wait inside their rooms for men to come to them, lead to a more long-term, gradual acquisition of wealth in circumstances in which the earner is more integrated into the local community. ${ }^{57}$ This is, of course, to pass over the position of those based in brothels, and, in general, the high prevalence of slavery, and the role of the lenones, complicates the relationship between price and income still further. A few women may have acquired enough money to purchase their freedom, but generally there is no way of knowing what proportion (if any) of the money she brought into a lupanar - or elsewhere - she actually received. ${ }^{58}$

The men of the Roman élite may have made, at least on a certain level, a straightforward equation between price and value, but this equation is not equally valid for the women themselves. Here a number of other considerations are relevant in relating fees to earnings and to broader economic aims. Much remains speculative, but it can certainly be argued that though the lupae of the streets and cemeteries presumably ruled themselves out of the running for the highest rewards a meretrix might receive, rewards entirely in the gift of some rich man, they might, when neither enslaved nor ruled by a leno, earn through their own labour a more than living wage. ${ }^{59}$ McGinn

53 This is the kind of distinction Davidson builds his hierarchy on, op. cit. (n. 23), 109-36.

${ }^{54} \mathrm{Ov} ., A m$. I.10.

ss See e.g. Høigård and Finstad, op. cit. (n. I 5), I 30-I, and also the remarks of White, op. cit. (n. 2), I 2- I 5. Of course, street-walkers may decide to pursue their career in a more relaxed fashion.

56 Høigård and Finstad, op. cit. (n. 15), 129

57 White, op. cit. (n. 2), I $3-16$ and $103-25$.

58 Priap. 40 presents itself as a poem from the prostitute Telethusa marking the purchase of her freedom, but this is the only hint at such a practice.
59 Juvenal (10.236-9) lambasts a man who left all his money to a whore who had been displayed for many years within the walls of a fornix, but the extremities of the case suggest that even more modest versions would have been rare, though the general risk of fortunes being lost in brothels is reflected in the various stories about the over-involvement of young men with meretrices which usually turn on their disinheritance, e.g. Quint., Inst. 7.4.20 and I I.1.82-3, and Calp. Flacc. 30 . 
estimates earnings of about ten sesterces a day for meretrices operating on the attested price scale, which is about twice the estimates for the daily wage of a male labourer, and there are various other indications that prostitutes might become wealthy, most strikingly Cato's story, as retold by Macrobius, that Larentia, 'meretricio quaestu locupletatem' ('rich from her earnings as a meretrix'), left large amounts of land to the Roman people on her death. ${ }^{60}$

It has to be said, however, that the people making the most money from prostitution were not the women themselves, or their families. Greed characterizes the leno or pornoboskos, not the prostitute; nor, to the same extent, her more familiar prostitutors. By and large prostitution forms part of the slave economy, so though the labour is hers the profits are not. And it is male rather than female lusts that are central; male rather than female conduct that is of most concern in the writings that touch on prostitution. The servile character of most Roman prostitution, its place in the wider pattern of the exploitation of unfree labour by the slave-owning classes, their exploitation of the constitution of the male sexual subject, and the ways women can be made to work at being the ultimate sexual object, becomes clearer in examining the intersection of the law and prostitution.

\section{LEGAL RECOGNITION AND REGULATION}

Roman prostitutes and their purveyors were recognized groups of persons within the workings of the legal system; indeed they were subject to considerable regulation. It was, however, their general place within society, their powers of personal action as its members, that were regulated as much as, if not more than, their particular profession; and this regulation was rather more incidental than systematic. The meretrix herself rarely appears in legal writings, but is usually designated by some version of the phrase, 'quae corpore quaestum facit' ('she who makes a living by her body'), and such a woman was, together with those who made a living by the bodies of others, penalized by a set of legal disabilities that were justified, more or less consistently, with reference to that most flexible of Roman legal concepts - infamia ${ }^{61}$ They were persons of such ill-repute that their rights as citizens were restricted, diminished, in various ways. However, since women lacked many of these rights, as women, anyway, the specific penalties connected with infamia had more bearing on the leno than either the lena or meretrix; what they did not have could not then be removed from them. This is made most explicit in relation to the provisions of the Praetor's Edict as it regulated litigancy, circumscribing the legal agency of various groups of people, as well as setting out the ways in which that agency might be exercised. Women can act only on behalf of themselves, while those who have incurred infamia can act also on behalf of a small number of specified others. ${ }^{62}$ Thus the Edict's list of infames is exclusively male, including he 'qui lenocinium fecerit' ('who engages in lenocinium'), the identifying activity of the leno, but not she 'quae corpore quaestum fecerit', for instance, as also those husbands and patresfamilias who commit various marital improprieties, but not wives. ${ }^{63}$

Even acting on his own account, however, it would have been a brave leno who ventured into a court, as several surviving declamations indicate. Orators slide easily from impugning the moral character of the leno, to impugning his juridical capacity. 'Tu te iure audes defendere' ('Do you dare defend yourself in law?') demands an unnamed speaker recorded by Calpurnius Flaccus as prosecuting a leno who had thus

\footnotetext{
${ }^{60}$ McGinn, op. cit. (n. 50), 24; Macr., Sat. I. 10. I6; this is, of course, not the only story told about Larentia and her lands, but that it could be told is significant none the less.

${ }_{61}$ On infamia see generally the remarks of $\mathbf{B}$. Levick, 'The senatus consultum from Larinum', $\mathscr{Y R S} 73$ $(1983)$, rog; and see also, on the particular issues discussed here, McGinn, op. cit. (n. I), 26-69, J. Gardner, Being a Roman Citizen (1993), 1 10-54,
}

and C. Edwards, 'Unspeakable professions: public performance and prostitution in ancient Rome', in J. Hallett and M. Skinner (eds), Roman Sexualities (1997), 66-95.

${ }_{62}$ Dig. 3.1.1.5 - women; 3.1.1.8 - infames, the others (mostly family members) on behalf of which they can act are specified at 3.1.I.I I.

${ }^{63}$ Dig. 3.2.I. 
presumed. ${ }^{64}$ For, he asserts, 'nihil ei licet in quem nihil non licet' ('nothing is lawful for him against whom nothing is unlawful'). Similarly, the one point at which the limitations on a prostitute's court appearances exceeded those of other women - her exclusion, on account of the disgraceful notoriety of her way of life, from giving evidence in any case brought under the Lex Julia de vi - must be regarded as actually doing little work. ${ }^{65}$ The claim that the very 'condicio personae' ('condition of the character') of a meretrix robs her of all fides - credibility or honesty - made by the pauper in the case of the hate-potion, represents a very obvious line of attack for anyone faced with the testimony of a prostitute on any matter. ${ }^{66}$

In all these declamations, except the last, the prostitutes are specified as slaves mancipia and ancillae - controlled, if not owned, by a leno; and it is this feature of his profession that is also most prominent in the definition of 'qui lenocinium fecerit' provided by Ulpian in his work $O n$ the Edict. ${ }^{67} \mathrm{He}$ specifies the group of persons thus classified by the law as follows:

lenocinium facit qui quaestuaria mancipia habuerit: sed et qui in liberis hunc quaestum exercet, in eadem causa est. sive autem principaliter hoc negotium gerat sive alterius negotiationis accessione utatur (ut puta si caupo fuit vel stabularius et mancipia talia habuit ministrantia et occassione ministerii quaestum facientia: sive balneator fuerit, velut in quibusdam provinciis fit, in balineis ad custodienda vestimenta conducta habens mancipia hoc genus observantia in officina), lenocinii poena tenebitur. Pomponius et eum, qui in servitute peculiaria mancipia prostituta habuit, notari post libertatem ait.

He engages in lenocinium who has slaves for hire, though he who conducts this business with free persons is in the same situation. He is liable to punishment for lenocinium whether this is his principal occupation, or whether he carries on another trade (as, for instance, if he is an inn- or tavern-keeper and has slaves of this kind serving and taking the opportunity to ply their trade, or he is a bath-keeper having, as happens in certain provinces, slaves hired to look after clothing in the baths who are attentive in this way in their workplace). And Pomponius says that he who, while in servitude, had prostituted slaves in his peculium, remains infamous after emancipation. ${ }^{68}$

The leno is, therefore, primarily a manager of slaves prostituted in taverns, inns, and bath-houses, as well as brothels. He may also himself be a slave, and there are a number of other indications that, even if not, he should still often be seen as a middle-man, running a business in which the major investment comes from, and main profits accrue to, people rather better placed in Roman society than himself. ${ }^{6}$

A similarly full definition of the meretrix and lena is also offered by Ulpian, but in relation to the Lex Julia et Papia, not the Praetor's Edict; that is, in relation to an enactment regulating the relationship between marriage, reproduction, and inheritance, rather than regulating the instrumental relationship between persons and the law. In the case of the Augustan legislation, moreover, the actual wording of the statute that Ulpian is clarifying is unfortunately lost, or displaced. However, it is clear that it was contrary to this law for freeborn men to marry infamous women, including prostitutes specified by some version of the phrase 'quae palam corpore quaestum facit' - lenae, and those manumitted by a leno or lena, among others. ${ }^{70}$ Ulpian explains:

\footnotetext{
${ }^{64}$ Calp. Flacc. 5 ; the same controversia is referred to at Sen., Contr. I0.1.13-I5, where a selection of sententiae abusing the leno is preserved, and, more briefly, at Rhetores Latini Minores 83. I. For similar attacks on the ethical and legal persona of the leno, see also [Quint.], Min. Decl. 385 , where a leno is attempting to bring an action damnum iniuria datum against a man who administered a love-potion to one of his slave meretrices.

${ }^{65}$ Dig. 22.5.3.5.

${ }^{66}$ [Quint.], Decl. Maj. 14.5.

67 Other declamations featuring prostituted slaves
}

include Calp. Flacc. 37; [Quint.], Decl.Min. 356, and, of course, Sen., Contr. I.2.

${ }^{68}$ Dig. 3.2.4.2-3.

${ }^{69}$ Dig. 5.3.27.1, for instance, ensures that rents from brothels can be claimed as part of an inheritance, for such establishments are run on the properties of many honesti viri; and see also CIL III.I $375^{\circ}$ which is also discussed below.

${ }_{70}$ For discussion of this provision, and the problems that surround it, see e.g. McGinn, op. cit. (n. 1), 70-104, S. Treggiari, Roman Marriage (1991), 62-3, and Gardner, op. cit. (n. 6I), 1 23-6. 
palam quaestum facere dicemus non tantum eam, quae in lupanario se prostituit, verum etiam si qua (ut adsolet) in taberna cauponia vel qua alia pudori suo non parcit. palam autem sic accepimus passim, hoc est sine dilectu: non si qua adulteris vel stupratoribus se committit, sed quae vicem prostitutae sustinet. item quod cum uno et altero pecunia accepta commiscuit, non videtur palam corpore quaestum facere. Octavenus tamen rectissime ait etiam eam, quae sine quaestu palam se prostituerit, debuisse his connumerari ... lenas autem eas dicimus, quae mulieres quaestuarias prostituunt. lenam accipiemus et eam, quae alterius nomine hoc vitae genus exercet. si qua cauponam exercens in ea corpora quaestuaria habeat (ut multae adsolent sub praetextu instrumenti cauponii prostitutas mulieres habere), dicendum hanc quoque lenae appellatione contineri.

We would say that a woman openly makes a living [by her body] not only where she makes herself available in a brothel, but also if (as is customary) she squanders her chastity in taverns, inns, and other places. Thus we understand 'openly' as indiscriminately - that is without selection - not a woman who commits adultery or fornication, but one who maintains herself in the manner of a prostitute. Likewise, because she has intercourse with one or two, having taken money, it is not understood that she has openly made a living by her body. Also Octavenus says, most correctly, that even a woman who makes herself openly available, without making a living, ought to be counted in this category. ... We call these women lenae who set out women for hire. We also understand as a lena she who leads this kind of life under another name. If a woman running an inn has slaves for hire in it (as many are accustomed to have prostituted women, on the pretext that they are servants of the inn), this must also be said to put her in the category of the lena. ${ }^{71}$

For Ulpian, then, a prostitute is a woman who makes her absolute availability into a way of life; not one whose sexual activity is, however wrong, essentially selective, nor one who only occasionally turns tricks. This way of life need not even be remunerative. It was juristically possible to separate the quaestum out from the vicis prostitutae without destroying it, though there cannot have been much call to do so among the non-slave women this law affects. The juristic definition of this way of life was still pretty stringent, however, though it clearly was a sexual position - one of complete openness - that was thus being lived, and the sexuality and the living impinge more closely on each other, are closer correlates, than in the case of other women. This stringency was also not just a legalistic phenomenon. Others too drew a sharp line between the professionally promiscuous, those who lived by their accessibility, and those women whose promiscuity was shaped by other considerations, who had not surrendered control over access to their bodies, even if they exercised that control woefully badly. Quintilian, for instance, considers the notorious Clodia to have been an impudica, an unchaste and immoral woman, but not a meretrix; though he acknowledges Cicero's application of the latter term to her during his defence of Caelius to have been an effective case of rhetorical exaggeration. ${ }^{72}$ And the Younger Seneca describes the transformation of Augustus' daughter Julia 'ex adultera in quaestuariam' ('from adulterer into mercenary'), from a woman who took scores of lovers to a woman who took money from men she did not even know. ${ }^{73}$ Economics and remuneration are thus back in the picture.

Ulpian's lenae might be in charge of these women (and apparently only women) who make a living by their bodies in a range of locations, indeed there is a persistent concern to cover all forms of prostitution and its organization in these juristic formulations. And a closer relationship between lena and meretrix than between leno and his goods emerges in poetry, though here the lena is more of a procurer of individual women than a manager of any kind of institution; while a remarkable third-century A.D.

${ }^{71}$ Dig. 23.2.43.pr-3 and 7-9; cf. 23.2.4 I.pr, where Marcellus implicitly interprets the legislative 'palam' rather differently, as signifying an openness of publicity, rather than of accessibility, as for Ulpian; other juristic usage also tends to favour Marcellus in this respect. However, since what Marcellus is arguing is that the 'palam' is an unnecessary qualification, he agrees with Ulpian that it is accessibility, not publicity, that is at issue in incurring infamia and the penalties of the Julian law. These points are also discussed at McGinn, op. cit. (n. I ), I 23-39.

72 Quint., Inst. 8.4.2; cf. Cic., Cael. I6.38.

${ }^{73}$ Sen., Ben. 6.32.I. 
inscription from Beneventum even commemorates Vibia Calybeni, a liberta lena. ${ }^{74}$ For neither the lena, nor the meretrix, however, can the provisions of the Lex Julia et Papia - the point of departure for Ulpian's definition - have been of much importance. This is not to say that matters of inheritance, particularly for their children, were irrelevant to these women, and their partners, in forming any union, but that a number of factors - the inability of slaves to marry, for instance, as well as the range of alternative relationships available, the compromised status of 'turpes personae' ('disgraced persons'), such as women who make a living by their bodies, as heirs, and the doubt surrounding the application of the Augustan legislation to the poorer sections of society - all conspire to reduce its significance in this respect. ${ }^{75}$ However, this law, and others, did play a part in regulating the place of the prostitute, and those who controlled her, in society more generally; it did act to formalize their denigration. This regulation restricted their rights, their powers of action, diminished their standing and agency, as punishment for their way of life. It should be stressed that it is the failure of individuals to conduct themselves in accordance with social norms and values that is being penalized, not its results. No verdict is being passed on the institution of prostitution itself, on its desirability or otherwise, just on its personnel as women and men living in the Roman state.

There were aspects of the institution that Romans did find problematic. Indeed there were even problems involved in the slave base of prostitution. A considerable amount of imperial legislation and juristic writing is dedicated to the restrictive covenant 'ne prostituatur' which could be attached to the sale of slaves and so forbid the purchaser to prostitute the slave. ${ }^{76}$ The Scriptores Historiae Augustae further report that Hadrian prohibited the sale of slaves to lenones (or lanistae) without cause, and Septimius Severus certainly gave the Urban Praetor the obligation to protect slaves from being prostituted. ${ }^{77}$ It was a rescript of the same emperor that laid down that a woman's servile quaestus did not affect her standing after emancipation and, in a similar vein, a freedwoman could not be required to perform services for her patron that harmed her reputation. ${ }^{78}$ None of these measures amount to anything like a serious attempt to prevent, or even curb, slave prostitution; but they do mark various points of difficulty and contradiction within the Roman legal system and the principles and values it enacted. That women should be so specifically forced to surrender their key asset their chastity - and so clearly condemned not to fulfill their proper role in society the procreation of legitimate children - was recognizably wrong, a contravention of basic social norms. But it occurred within structures of power - the family and slavery - just as basic to Roman society, to which certain other benefits also accrued from its occurrence. There was nothing to be done on the fundamental level, but that some patresfamilias might seek to prevent members of their household, for whom they had a certain responsibility and whose conduct also reflected back on them, from meeting this fate even after they had passed out of their direct control, and that the state might also try to intervene around the edges, makes sense too, as do the limited legal mechanisms adopted. ${ }^{79}$

The other legal restriction on becoming a meretrix, that is the Tiberian senatusconsultum prohibiting women of equestrian (and presumably also senatorial) rank from making a living by their bodies, arises from a rather different set of circumstances and

\footnotetext{
74 On the poetic figure of the lena see K. Sara Myers, 'The poet and the procuress: the lena in Latin love elegy', $\not{F} R S 86$ (1996), 1-2I; and see CIL IX.2029 for Vibia.

${ }_{75}$ Dig. 37.12.3.pr covers the removal of turpes personae as heirs; and the Gnomon of the Idiologos actually sets a minimum inheritance below which the Lex Julia does not apply, which may reflect practice elsewhere even if not the letter of the law, see Treggiari, op. cit. (n. 70), 78-9. There are sufficient legal (and other) references, however, to indicate that meretrices did marry, or form other kinds of legally recognized unions, see e.g. Dig. 23.2 .24 and 47 ; $25 \cdot 7 \cdot 3 \mathrm{pr}$ and $48.5 \cdot 14.2$.
}

${ }^{76}$ See W. W. Buckland, The Roman Law of Slavery (1908), 70-1 and 603-4 and T. McGinn, 'Ne serva prostituatur: restrictive covenants in the sale of slaves', ZRG 107 (1990), 315-53 and now also McGinn, op. cit. (n. I), 288-319.

77 SHA, Hadr. 18.8; Dig. I.I 2.1.1 8. The phrasing of the Severan instruction suggests that the Praetor's duties were connected with the enforcement of 'ne prostituatur' covenants.

${ }^{78}$ Dig. $3 \cdot 2.24$ and $38 \cdot 1 \cdot 3^{8 p r}$.

${ }_{79}$ McGinn, op. cit. (n. 76), offers a similar explanation, but one which focuses more on the preservation of the household's honour in all this. 
contradictions. This, as Tacitus tells it, was a rapid response to the efforts of one Vistilia, the scion of a praetorian family, to avoid the heavy penalties of the Julian law on adultery by advertising her 'licentiam stupri' ('sexual licence') with the aediles, and thus clearly removing herself from the ranks of the matresfamilias with whom adultery was committed. ${ }^{80}$ A further senatusconsultum closed off engagement in lenocinium (and acting) as a possible escape route for women in similar straits, but explicitly so, rather than by banning anyone from taking it up at all. ${ }^{81}$ The implication, it should be stressed, is that Vistilia is the first and last aristocrat to respond to the clear incentives of the Augustan legislation in this way; moreover, the real issue here is adultery not prostitution.

The role of the aediles in relation to prostitution, however, raises the issue of a more systematic kind of regulation of the profession and its organization at Rome. Unfortunately, the evidence on the subject is extremely slight. Tacitus' account of Vistilia's recourse to it is the only surviving mention of some kind of aedilician register of prostitutes at Rome; a register which he claims has an essentially penal purpose, though one better befitting an earlier, more innocent, age, when publicity in itself was considered punishment enough for the unchaste. To this can be added a passing reference by Seneca the Younger to places, connected with prostitution, that 'aedilem metuentia' ('fear the aedile'); though what exactly they fear from him is unclear. ${ }^{82}$ Whatever aedilician control of prostitution there was, however, must have been eclipsed following the introduction by the emperor Gaius of a raft of new income-generating measures including a tax on the earnings of meretrices, which, Suetonius states, was initially collected by the publicani, but quickly handed over to the Praetorian Guard in order to maximize revenues for the imperial treasury. ${ }^{83}$ As McGinn says in his extensive study of the subject, this maximization was as much about the resources the military brought to the enterprise as about the advantages of direct collection per se; the Praetorians had the capability both to keep a careful track of all women making a living by their bodies in the city, and to ensure regular payment. ${ }^{84} \mathrm{His}$ suggestions about the effect of this measure on the practice of prostitution itself are, however, rather less convincing, as he sees this tax as basically and beneficially 'legitimizing' prostitution, though also increasing the control exercised over those who paid it, a control he admits might be problematic. ${ }^{85}$

For Caligula's tax crosses no lines of criminalization, contravenes no principles of public policy; there is none of the normal, indeed necessary, context for this talk of 'legitimation'. Instead it acts in collusion with the other circumstances of Roman prostitution, both legislative and otherwise. It effectively exploits the situation in which prostitution is entirely licit, but its personnel are legally and socially compromised; not disallowed but disadvantaged. This is revenue raised on the (substantial) earnings of women and slaves, persons of ill-repute and restricted juridical agency, though not illegality; persons who could not defend themselves from imperial depredations, and who were unlikely to find any champions amongst the honourable and powerful, though their profits might be affected. It is, therefore, a tax on vulnerability, on a lucrative vulnerability, which was basically recognized for what it was by Suetonius, who has it motivated entirely by greed, and by later Christian writers who put the failure of a succession of Christian emperors to stop profiting from a trade to which they were now

80 Tac., Ann. 2.85

81 Suet., Tib. 35.2; Dig. 48.5.11.2; and see also Levick, op. cit. (n. 6r).

${ }^{82}$ Sen., Vit. Beat. 6.7 .3 ; the case of the meretrix Manilia and the aedile Hostilia has also been used as evidence of this register, but is less clear in this respect than is often suggested.

83 The introduction of the tax is described in Suet., Calig. 40 and Dio ap. Xiph. 59.28.3; its collection in the second century A.D. by both publicani and troops is witnessed by at least two receipts on ostraka from Egypt (O.Wilck. 83,O.Cair.GPW 6o, and see also $O . E d f o u(7 \mathrm{I})$, the bilingual inscription of the tax law from Palmyra (CIS II.iii.3913), and an inscription from Chersonesus on the Black Sea (CIL III.1 3750); I. Portes. 67 also records a harbour passage tax for prostitutes at Coptos on the Red Sea, but the structure of the tariff is too poorly understood to make much of it.

${ }_{84} \mathrm{~T}$. McGinn, 'The taxation of Roman prostitutes', Helios 16 (1989), 87; and see the further comments of R. Bagnall, 'A trick a day keeps the tax man away? The prostitute tax in Egypt', BASP 28 (1991), 5-12 and now also McGinn, op. cit. (n. I), 248-87.

${ }_{85}$ McGinn, op. cit. (n. 84), 80-6 and 98-9. 
at least notionally inimical down to the size of the revenues involved. ${ }^{86}$ And far from ameliorating that vulnerability, both the economic pressure exerted by the tax itself and the military means of its collection exacerbated it.

Only speculation is possible concerning the increase in productivity the tax would presumably have forced, and the impact it might have had on the relative merits and demerits of different forms of prostitution; but there is clear evidence that the collection of the tax was accompanied by violence and corruption. ${ }^{87} \mathrm{~A}$ late second-century A.D. inscription from the Black Sea town of Chersonesus preserves, in fragmentary form, a decree from the provincial governor, and various imperial instructions, issued in response to local complaints about the extortion practised by the garrison charged with gathering revenue from prostitution; complaints and instructions which also refer to similar problems, and their resolution, in the past. ${ }^{88}$ The grievances set out and responded to seem to centre around threats offered to, and excess monies taken from, those whom the soldiers considered to be in charge of the trade, and the most rewarding objects of their attentions: that is various leading citizens of the town. It is they who have protested, and been answered in the form of orders to the army to behave itself properly in general, and to restrict its activities to actual places of prostitution, rather than calling at the homes of the wealthy in particular. Extortion must have been even more endemic lower down the social order, and most vulnerable to violence and intimidation would have been the independent operative, the meretrix who acted entirely on her own behalf. The leno or lena could provide protection from the most arbitrary abuses, especially if they were both well-organized and well-connected, making working for them more attractive, despite the sacrifice in self-determination entailed, for those who had any choice in the matter. Comparative material provides good parallels for the way this kind of official intervention serves to bolster the position of, and increase the exploitative possibilities for, those who could stand between the authorities and their victims. ${ }^{89}$

Indeed the Chersonesus inscription refers to the tax at issue as being levied on lenocinium and it is lenones that are the focus of the emperor 'Theodosius' first faltering move away from the Christian state's participation in the profits of prostitution. ${ }^{90}$ 'This is, in many ways, a tax on prostitution rather than prostitutes, and it reveals and reinforces the position of the main beneficiaries of the business, the lenones and, behind them, the élite. Against this, however, must be placed the fact that the two most straightforward Egyptian receipts for the payment of the prostitute tax - the telos hetairikon - are issued to women, presumably the hetairai themselves. ${ }^{91}$ But it was not the military who collected the tax in Egypt, so perhaps this evidence should be placed beside, rather than against, that from elsewhere, and alongside a summary account of farmed taxes levied on a market held in Oxyrhynchus in A.D. I55/6 in which koineia

${ }^{86}$ This is expressed most clearly by Evagrius at $H E$ 3.39 when he discusses the eventual abolition of the tax by Anastasius in A.D. 498. And it is within the context of a Christian Empire with a new public policy towards prostitution that legitimation becomes an issue, as Evagrius points out.

${ }^{87}$ Its economic effects will have depended, in part, on whether the amount of the tax - set at the amount received for a single concubitus - accrued daily, as McGinn argues (op. cit. (n. 84), 9o) or monthly, which is the more traditional view. The question is not really resolvable, but Bagnall (op. cit. (n. 84), 9-12) opens the way to a possible reconciliation between the evidence that suggests prostitutes were taxed much more heavily than other earners - that is the shocked report of Suetonius, the survival of the tax for so long under the Christian emperors, and Evagrius' account of its eventual demise - and the evidence of its collection in Egypt and Palmyra which puts it more in line with normal, monthly, accruals. For, as he points out, there is no reason to assume uniformity in implementation across the Empire; moreover, it seems to me suggestive that these latter pieces of evidence come from contexts where collection was by tax-farmers, not the military. McGinn also moves in a more flexible direction at op. cit. $(n, 1), 264-8$ and $274^{-86}$.

${ }_{88}$ CIL III. I3750 = B. Latyschev, Inscriptiones Antiquae Orae Septentrionalis Ponti Euxini Graecae et Latinae $\mathrm{I}^{2}$ No. 404; and see discussion by McGinn, op. cit. (n. 84), 88-90 and op. cit. (n. I), $261-4$.

89 On the legal repression that led to the development of a pimp system in late nineteenth-century England, for instance, see Walkowitz, op. cit. (n. 2), 2 IO-2I.

${ }^{90}$ CIL III.1 $375^{\circ}, 36$ and NTh 18.

91 See Bagnall, op. cit. (n. 84) for details. I would further suggest that $O . E d f o u$ I $7 \mathrm{I}$, which not only contains a broken text, but is also made out to a known poll-tax payer from a well-attested Jewish family, could well be made out to a profiteer from prostitution of the kind met elsewhere, rather than an actual pimp or simply the victim of a general apportionment of a shortfall in the telos hetairikon which are the two possibilities discussed by Bagnall. 
(thought to be municipal brothels) are taxed as units. ${ }^{92}$ All can be taken as a useful reminder of the undoubted variation in prostitutional practice, its social position and patterning, across the vast expanse of the Roman Empire.

\section{PATTERNS OF SLAVERY AND PROSTITUTION}

The authorial élite of the Roman Empire thus viewed prostitution as an institution through which, for basically economic reasons, women were made and marketed as sexual objects of a certain, approved, type for the general populace. This was, then, a sex industry, but one in which the women were considered (and, through slavery, concretely constituted) more as products than producers, more as wares than workers; they were approved only as sexual objects for men, not as themselves, as women, and certainly not as sexual subjects. The general populace mainly meant the poor, including slaves, but also the rich. For them the meretrix counted among a whole range of sexual choices; but they could certainly also partake of the goods on offer to everyone, so long as they conducted themselves properly towards them and their milieu. This indeed is a central concern of the élite discourse on the subject; though whether it was a concern shared in any way by the more humble and usual brothel clientele is unknown.

This was not just how the élite viewed the institution of prostitution, it was also how the state, their state, shaped it. The law penalized the meretrix and the leno, or lena, diminishing their standing in society, their ability to act as members of the imperial community; but it protected, in various implicit and explicit ways, the customer and the investor, the less direct profiteer from prostitution. It enabled women to be forcibly prostituted, to have their bodies repeatedly sold under them - their owner being the one who gained, as all monies legally accrued to him and from which he provided her livelihood as he chose. The emperor also participated in, even deepened, this exploitation, with his tax on prostitutes' earnings. 'The impact of this tax on the historical record, however exaggerated in places, indicates the economic significance of prostitution; and it may also stand as a symbol of the more generally integral position of this institution in imperial society. ${ }^{93}$

In one sense, therefore, external factors bore down especially hard on the Roman meretrix, leaving her little room for manoeuvre, little agency at all. However, for those outside the framework of slavery itself, it is not clear that this was in fact the case. Imperial Rome was a divided society to an extent almost unimaginable now in the modern West - the pattern of formal penalties and rewards woven into its legal system, both by broad concepts such as infamia and specific provisions such as those in the Augustan marriage legislation, were really relevant only to a select few. It was important that a wealthy man who owned or visited a brothel did not find his powers of litigation and inheritance compromised thereby; but it mattered little to the women inside, they had separate concerns and may not even have been aware of the legal repercussions of their actions. It is not that the outside world was entirely irrelevant, but that it was the views of the poor, amongst whom meretrices lived and worked, rather than the rich, who wrote about them, that impinged on the consciousness and experience of these women. It was within these communities that their own attitudes to a career in prostitution would be formed, and within these economies that such a career was pursued; but so little can be said about this part of the Roman world that the meretrix is left as an actor without a stage.

The writings of the rich on the subject generally emphasize this distance between the worlds inhabited by the author and the prostitute, even if the two types of persons

${ }^{92}$ P.Lond. inv 1562 verso, 19-20, published and discussed by J. Rea in $Z P E_{4} 6$ (1982), $191-209$.

93 It is worth remembering, when reading Evagrius' account of arguments by those opposed to the abolition of this tax that it would leave the state unable to pay the army or serve God in the manner to which he was accustomed, the massive size of the global sex industry today and the fact that UN reports in the I 980 os estimated that more money was being made in the trafficking of women, mostly for prostitution, than smuggling drugs or arms (see, e.g. S. Altink, Stolen Lives: Trading Women into Sex and Slavery (1995), 2). 
occasionally met. Not only are meretrices clearly positioned, in a number of ways, right at the other end of the social scale, perhaps even so far removed as to be not on the same scale at all, but also women who are of the ruling classes are not meretrices, are rarely even accused of being such. The woman against whom the figure of the meretrix is marshalled is the mistress of elegy and epigram, not the matrona; and even here it is the gap between mistress and meretrix that is exploited, not their elision, there is no expansive dilution of the category of meretrix to include loose women more widely. The behaviour of the matrona was of concern, and it was variously regulated, but the meretrix was too far away from her to be of much assistance in this respect. The problem of her sexual conduct, especially of her potential for adultery, was dealt with very much on its own terms. Indeed adultery, a real (if much exaggerated) issue among the élite and an activity they actually sought to prevent, was much more harshly punished by the law than prostitution, an issue of the ordering of the rest of society in relation to the élite, an activity not to be prevented but kept in its place; and adulterer also proved the stronger term in speech, as moecha and adulter are derogatory synonyms for meretrix, not the other way round. Vistilia recognized this as she moved herself from the harsh reality of the threat of a prosecution for adultery into the gentler unreality of the aedile's list of the sexually available. ${ }^{94}$

It is not that being an adulterer was deemed worse than being a prostitute, for it is the utter depravity and degradation of prostitution - proper prostitution in which money changes hands, not a more loosely constituted whoredom - that is the worst Juvenal and Seneca can throw at Messalina and Julia, but that the two were, from the perspective of the wealthy writer, two different kinds of women, separated by an enormous social gulf if sexually more proximate. 'The image of the 'meretrix Augusta' is an incredible one, in all senses of the word, and is both stronger and weaker for it. Juvenal exploits its potency in his particular poetic programme, but more mundane moralists generally respected the distance between the matrona and adulter dyad on the one hand, and the meretrix on the other. Thus the meretrix herself is again excluded from these élite literary conversations. Again it is a quite differently located (and now lost) set of conversations in which all manner of claims and counter-claims may, or may not, have been made by and about meretrices and their neighbours that is of real relevance.

These points and patterns, however, fit neatly into neither the history of female labour nor the history of female sexuality, though both work and sex are significant parts of the story. Social policy, even if construed most broadly, takes up only some of the slack, for it is policies towards things other than prostitution itself that are of most importance. Moreover, it is unclear whether it would be possible, even if the evidence from the ancient world was commensurate with that used by White or Karras, to write a history of Roman prostitution that resembled either of theirs; a verdict which is certainly not critical, since both predict it, more or less explicitly. Access to their kinds of materials would undoubtedly make a difference, but a central problem, or pair of problems, would remain. For, on the one hand, the professionalism of the meretrix, the sense in which she definitely makes her livelihood with her body, is engaged in economic activity, is unquestioned; she is not 'completely defined by her sexuality'. On the other hand, her professionalism, in the sense that it implies a degree of ownership of, and control over, that economic activity, the making of her livelihood, is challenged by the involvement of slavery in prostitution, the way it constitutes the women as goods as much as workers. Furthermore, slavery must have had an impact on the way meretrices

\footnotetext{
94 McGinn, op. cit. (n. I), I 40-2 I 5, argues (inter alia) that the Augustan adultery law deploys the categories of meretrix and leno against adulterous matronae and their complaisant husbands, both as deterrent and punishment. The relevant legal notions (especially that of lenocinium) were certainly part of the juridical matrix within which this legislation was formulated and elaborated, but McGinn's particular points are harder to make. For the main vehicle through which he claims the assimilation of adulterer
}

to prostitute was achieved - the toga both were allegedly meant to wear - is problematic in many respects, and McGinn has to strengthen the slight contemporary evidence by recourse to later Christian writers who are, needless to say, participants in a rather different moral discourse. In a sense this just goes to emphasize that, in contrast with what was to follow, remarkably few women of the pagan Roman world were called 'whores', at least in polite society. 
were understood as a sexual category as well as on their status as workers. It may, for instance, have contributed both to their sexual objectification and the separation of meretrices from, rather than conflation with, other women, indeed it probably helped foster the divisions between rather than commonality among Roman women more generally.

A full assessment and understanding of the impact of slavery on prostitution, however, is complicated, if not impeded, on two scores. The first is that within modern debates on the sex industry there are arguments that prostitutes cannot, by definition, attain ownership of, or control over, their situation; that prostitution has an intrinsic affinity with, an innate tendency towards, slavery. That is there are those who (somewhat ironically given their rhetorical use of a more metaphorical notion of slavery) would claim that the existence of juridical slavery, of large numbers of prostitutes who are juridical slaves, makes little or no difference to the plight of the prostitute, or to the wider evil prostitution participates in. There are two main ways in which such antiprostitution, 'abolitionist', arguments are advanced. ${ }^{95}$ The more traditional approach, beginning with the late nineteenth-century campaigns against the 'White Slave Trade', is to characterize prostitution as something innocent young girls are forced into, as the domain of cruel and violent pimps and organized crime, to whom huge profits accrue while the women themselves have to make do with more meagre takings. More recently, however, the issues of coercion, of consent and control, have been discounted in favour of seeing the problem as residing in the very nature of the transaction around which the institution of prostitution is constructed; this is where prostitution is taken to resemble slavery. For prostitution inherently compromises the personhood, the subject-status of the prostitute while enhancing the manhood, the subject-status and power, of the purchaser; it thus assimilates, in a gender specific way, the prostitute to the position of the slave and the purchaser to that of the master ${ }^{96}$ More precisely, however, prostitution is to be classified as a form of sexual violence against women, which is a structural fact, unaffected by its concrete circumstances or by the actual views of either party; and it is to be opposed, abolished, on that basis. It is against these kind of assertions, and to normalize the position of the prostitute in society more generally, that others, importantly including much of the prostitutes' rights movement, define prostitution as 'sex work'; chosen on the same basis as other types of work, and experienced in ways that depend on the conditions in which the work takes place rather than the terms on which the sex takes place. ${ }^{97}$ They argue that what is being sold is not the self, or degradation, or even the body, but the woman's time and labour; and even that making men pay for this erotic service, its commodification, may actually be positively selfdetermining for women and subversive of the dominant sexual order. They speak not of the 'free-choice' to become a prostitute, for in the contemporary labour market freechoice is a chimera, but say rather that many women have made a 'rational choice' in this matter; and that efforts should be made to improve the conditions of the trade, to increase women's autonomy and control and decrease third-party involvement, state repression and social stigma, rather than forbidding them this option. These are then reformers and transformers rather than abolitionists, those for whom prostitution may become slavery, but is not necessarily so.

Historically speaking, the view that the organization of prostitution is automatically coercive has little support. Recent studies in particular have put more emphasis on the rationality of the choice to go into prostitution in contexts where women's economic options are significantly circumscribed, and the ways women found of achieving their objectives, of resisting degradation, in the profession. 'Choice' not compulsion was the main mode of entry into prostitution in late nineteenth-century Britain and America,

${ }^{95}$ For a recent discussion of these issues within the abolitionist tradition see e.g. S. Jeffreys, The Idea of Prostitution (1997).

96 This comparison is based on the definition of slavery formulated by Orlando Patterson in his Slavery and Social Death (1982), in particular his highlighting of the dynamics of honour and degrada- tion within slavery. Of course, it is not the prostitutepunter relationship that is the slave-master one in actual slave prostitution.

${ }_{97}$ For a recent discussion within this tradition see e.g. W. Chapkis, Live Sex Acts: Women Performing Erotic Labour (1997). 
despite the claims about the magnitude and methods of the 'White Slave Trade'; and those who campaign against the traffic in women today estimate that force and deception are implicated in between ten and twenty per cent of recruitment into prostitution both within South East Asia and of foreign women into the sexual marketplaces of Western Europe. ${ }^{98}$ That is what might reasonably be taken as a rough reversal of the probable proportions of slave and free prostitutes in the Roman world. Nor are prostitution and pimping synonymous. The sex trade in colonial Nairobi White describes is free from third-party involvement, male or female; and outside of slavery, and the existence of formal ownership, it is state regulation and repression, especially the criminalization of the prostitutes themselves, that establishes the conditions for, and encourages the growth of, the systematic exploitation of prostitutes by the managers of clubs and brothels, and pimps. ${ }^{99}$

On the issue of whether, even in the most favourable conditions, prostitution is abusive, directly damaging to the prostituted women themselves and indirectly detrimental to the position of women in society more widely, the historical view is, of course, less clear. Either way, however, it does seem somewhat perverse to discount issues of consent, coercion, and control completely; to create absolutes rather than a complex continuum of abuse and empowerment, degradation and achievement. And, on any such scale, slave prostitution is going to come at the very bottom. It is the site where all the most harmful and oppressive conditions for the prostituted women, if not wider society, converge and formally congeal. There are certainly free women who approach, and have approached, this position. Those currently forcibly trafficked from South East Asia for instance, who find themselves virtually imprisonned in brothels or clubs in Amsterdam or Tokyo and saddled with an enormous debt notionally incurred in their transport and settlement which must be paid off before they see any of their own earnings. But however close these groups of women come in practice, there is still a formal difference between them, of juridical status and the legality of their treatment, and it is not an irrelevant consideration. 'Non-slaves always possess some claims and powers themselves vis-à-vis their proprietor', as Orlando Patterson says, and it is true however hard they may find it to pursue those claims or exercise those powers in the circumstances; otherwise slavery vanishes as a distinct institution. ${ }^{100}$ Indeed, the overall effect of the argument that prostitution inherently imitates slavery is to blur this distinctiveness, to overlook the fact that the relationship between prostitutes and slaves may actually be one of identity not resemblance.

Moreover, this article has tried to draw attention to ways in which prostitutes' legal status made a difference in the Roman world itself, to the lives and livelihoods of the women themselves. However, having insisted that juridical slavery does matter, the second difficulty now comes into play; for it is at this point that the historical comparisons are at their weakest. It is patterns of prostitution in societies without large numbers of slaves that have been best studied; while the impact of patterns of servitude on prostitution in slave societies has received little attention. Both slavery and prostitution are expanding areas of recent historical scholarship, but separately not together. Moreover, the most obvious place to look for comparisons - the American South - turns out to be rather awkward in this respect, though illuminating in others. For there slaves were not commercially prostituted on any substantial scale; demonstrating that the particularities of the Roman world are not reducible to the centrality of slavery within it, to the simple existence of opportunity and motive for slave prostitution.

98 See e.g. Walkowitz, op. cit. (n. 2), I $3-41$, and Hill, op. cit. (n. 2), 63-1 66 , for the past and Chapkis, op. cit. (n. 96), 47-8 for the present.

${ }_{99}$ White, states categorically (op. cit. (n. 2), 6) that, 'There were no pimps in Nairobi or anywhere else in Africa, outside of Johannesburg in the I 890 '. She also offers a range of evidence to support her wider claim that, "men and male control enter prostitution only after the state does' (4). 'This claim ties in with the conclusions of other recent studies, but slavery provides an exception.

${ }_{100}$ Patterson, op. cit. (n. 96), 26. 
In their controversial econometric survey of Southern slavery, Fogel and Engerman offer two reasons for this absence. ${ }^{101}$ First, that there was no demand, on account of white men's 'racist aversions' to sex with black women; second, that there was no supply, on account of the greater profits to be made from female slave labour in the fields than in brothels. As has often been pointed out, however, white men had no such aversion to sex with black women outside the frame of commercial prostitution. Indeed it has been suggested that it was instead the ease with which female slaves were sexually exploited by white men who had control over them which acted to reduce the numbers prostituted. ${ }^{102}$ Rome, however, contradicts this argument, or at least renders it insufficient. Their own slaves certainly counted amongst the acceptable sexual objects and options for élite men in the Roman Empire, indeed, the dissenting Musonius Rufus implicitly locates them as the most socially acceptable, with prostitutes next, and other unmarried and otherwise unattached women after that. ${ }^{103}$ But this also shows, as do many more orthodox voices, that the two were not mutually exclusive, and there were those who suggested that the reverse is true, that one form of licence inevitably leads to another. Of course the clientele of Roman brothels was primarily poor, they did not depend on aristocratic, slave-owning patronage for their success, and it may well be that it is in this context that demand was lacking in America. That the lesser degree of urbanization in the Southern States, the less developed and more controlled slave and freed populations of what towns and cities there were, failed to produce a significant sexual market, engendered a demand that could easily be met by the casually organized prostitution mainly of poor whites. ${ }^{104}$ The relatively restricted role of prostitution, and slave prostitution in particular, in the wider sexual economy of the American South thus comes primarily from the economic rather than sexual side of the equation; from the economic unattractiveness of prostitution as an investment for slave-owners, rather than its sexual unattractiveness given the alternatives. The traditional aristocratic response to any set of choices is, after all, to opt for both, or all, as the Romans amply demonstrate.

There are other differences between the American South and the Roman Empire which have a bearing on the ways in which slavery and prostitution intersect in each case. Each has its own slave-holding ideology and sexual order, entwined and enforced in their own ways, and bound up in America with a specific racial order. Thus the legal position of prostitution diverges between the two, as indeed does the notion of prostitution itself, and the wider security and certainty of their respective slave systems. In the Southern States, for instance, slave-owner investment of slaves in prostitution would have been investment in a criminal as well as morally reprehensible business, and it would have offered abolitionists, who already attacked slavery as synonymous with a very loosely defined prostitution (since it made women sexually available), a gift ${ }^{105} \mathrm{At}$ this point, therefore, prostitution was a more clearly and commonly identifiable evil than slavery, which was to be tarred with its brush rather than vice versa. Whereas in

${ }^{101} \mathrm{R}$. Fogel and S. Engerman, Time on the Cross: The Economics of American Negro Slavery (1974), i 35. They offer only one statistic about the absence of slaves from prostitution - that in 1860 only 4.3 per cent of Nashville prostitutes were black (and none were slaves) while 20 per cent of the overall population was black - but that Southern prostitutes were overwhelmingly white, and even more overwhelmingly free is, however, not disputed.

102 See e.g. V. Bynum, Unruly Women: The Politics of Social and Sexual Control in the Old South (1992), 79-80 and C. Clinton, The Plantation Mistress: Woman's World in the Old South (1982), 221.

${ }_{103}$ Muson., Fr. I 2 (Lutz).

${ }^{104}$ I take support for this suggestion from the places, mostly busy ports, where prostitution, including of some slaves, did take significant root in the Americas, see e.g. T. Lockley, 'Crossing the divide: interracial sex in antebellum Savannah', Slavery and Abolition 18 (1997), 159-73. This is also what seems to have happened to more slaves in Brazil, see e.g. M. Karasch, Slave Life in Rio de faneiro, $1808-185^{\circ}$ (1987),
207, and the Caribbean, see e.g. B. Higman, Slave Populations of the British Caribbean, $1807-1834$ (1984), 231-2 and H. Beckles, 'Black female slaves and white households in Barbados', in D. Gaspar and D. Hine (eds), More than Chattel: Black Women and Slavery in the Americas ( 1996), I $21-2$.

105 The complaint of Mary Boykin Chesnut, the abolitionist wife and daughter of major slave-owners, that, 'we live surrounded by prostitutes', is one of her key objections to slavery; that is the wrongs it perpetrates against white women married to men who make full use of these black 'prostitutes' (C. Van Woodward (ed.), Mary Chesnut's Civil War (198I), 29). Proslavery ideologue William Harper, on the other hand, praised this state of affairs, claiming that the 'prostitution' of all slave women was a benefit both to the women themselves and to the white men who were 'less depraved' by intercourse with them than they would be by intercourse with 'females of their own caste' (D. G. Faust (ed.), The Ideology of Slavery: Proslavery Thought in the Antebellum South, $1830-1860$ (1981), 104-7). 
the Roman world, prostitution was no less legal than slavery and only slightly less unobjectionable. A few did object, but while Dio Chrysostom might attack the pornoboskoi and their avarice and Musonius might criticize the lack of élite male continence, neither raised a murmur against slavery itself, the institution which enabled and encouraged these profits and profligacy. ${ }^{106}$

\section{CONCLUSION}

The complexity of the subject is thus underlined once again. The multiplicity of factors involved in the formation and workings of past prostitutions is stressed. It is to try and embrace (but certainly not exhaust) all these issues that this article addresses itself to the broader construction of the 'sexual economy' of female prostitution in the Roman Empire; and to the notion that this construct - the interplay of sex and money, of labour and livelihood, in their wider surroundings - is both different from and similar to those from other societies, slave or not. There is, it is suggested, a particular Roman configuration of elements also to be found elsewhere, and understanding it as such, within the context of other possibilities and perspectives is helpful. It is particularly helpful in making some room for the women involved, for their aims and actions, life and work; though it has not been possible to fill in that space with anything much more tangible than suggestion and innuendo. These gaps, their openness rather than their occlusion, are none the less crucial in the move towards the better understanding of Roman prostitution as a phenomenon fully integrated into Roman imperial society.

Wellcome Institute for the History of Medicine/University College London

\footnotetext{
106 On the general security of Roman slavery see P. Garnsey, Ideas of Slavery from Aristotle to Augustine (1996).
} 